\title{
Aplikasi Pembelajaran Interaktif "Perang Padri" Menggunakan X-Box Kinect untuk Meningkatkan Minat Siswa dalam Mempelajari Sejarah Bangsa Indonesia
}

\author{
Azka Ramadhona $^{1 *}$, Meilany Dewi ${ }^{2}$, Silvana Rasio Henim ${ }^{2}$ \\ ${ }^{1}$ Program Studi Teknik Informatika Politeknik Caltex Riau, Pekanbaru 28265 \\ ${ }^{2}$ Program Studi Teknik Komputer Politeknik Caltex Riau, Pekanbaru 28265
}

\begin{abstract}
Abstrak
Pengenalan dan pemahaman sejarah yang benar berperan penting dalam pembentukan karakter berbangsa. Perang Padri adalah bagian dari sejarah bangsa Indonesia yang perlu dikenalkan. Perang ini mengajarkan kepada kita bahwa dua kelompok masyarakat yang bertikai dapat bekerjasama untuk mempertahankan tanah air mereka dari penjajah. Seringkali mata pelajaran sejarah disampaikan melalui membaca buku sehingga tidak menarik bagi siswa Sekolah Dasar. Paper ini memaparkan penelitian yang dilakukan untuk meningkatkan minat siswa dalam mempelajari sejarah. Sebuah aplikasi interaktif pembelajaran sejarah "Perang Padri" telah dikembangkan menggunakan X-Box Kinect. Aplikasi ini memilki sensor yang memfungsikan gerakan tangan sebagai kontrol gerakan. Aplikasi yang berbasis video animasi 3 dimensi ini juga dilengkapi dengan soal-soal untuk menguji hasil kegiatan belajar. Lima guru yang terlibat sebagai responden menilai bahwa aplikasi ini interaktif dan dapat menjadi alternatif media dalam menyampaikan pelajaran sejarah. Penilaian yang diberikan adalah $90 \%$ untuk aspek materi, $82 \%$ untuk aspek umum, 81.3\% untuk kualitas tampilan, 79\% untuk penyajian materi, dan 84\% untuk interaksi pengguna. 40 siswa yang dilibatkan dalam proses penilaian memberikan nilai $82 \%$ dan 79,3\% untuk aspek pembelajaran dan desain visual. Hasil evaluasi menunjukkan bahwa penyajian materi pelajaran sejarah melalui aplikasi yang dikembangkan mampu meningkatkan secara signifikan minat siswa Sekolah Dasar dalam mempelajari sejarah bangsa Indonesia.
\end{abstract}

Kata kunci: Sejarah; Perang Padri; Xbox; Kinect; aplikasi interaktif; animasi 3D

\begin{abstract}
[Title: “Perang Padri” Interactive Learning Application using X-Box Kinect to Improve Student's Interest in Studying Indonesian History] Proper knowledge and understanding on national history plays an important role in shaping the character of a nation. Perang Padri (Padri War) is one part of Indonesian histories that needs to be introduced. It taught us that two disputing clans can work together to defend their land against invaders. However, such subject is usually taught trough book reading which makes it uninteresting for elementary school's students to learn. This paper presents a research to improve fifth grade students's interest in learning history. An interactive history learning application called "Perang Padri" has been developed using X-Box Kinect with hand as an input of motion control. This application is based $3 D$ animation video with trivial questions to test the result of the learning process. Five teachers which are involved as respondents in the application testing process concluded that the application is interactive and can be an alternative history learning method. They gave $90 \%$ for material aspect, $82 \%$ for general aspect, $81.3 \%$ for display quality, $79 \%$ for subject delivery, and $84 \%$ for user interaction. 40 elementary students gave rate $82 \%$ and $79.3 \%$ for the learning and application visual design. These results show that delivering history subject through the developed application increases elementary students' interest in learning Indonesian history, significantly.
\end{abstract}

Keywords: History; Padri war; Xbox; Kinect; interactive application; 3D animation

\section{Pendahuluan}

Penanaman ingatan sejarah bangsa selalu menjadi bagian dari sistem pendidikan. Pengenalan dan pemahaman sejarah yang benar berperan penting dalam pembentukan karakter suatu bangsa, khusus nya sejarah

\footnotetext{
*) Penulis Korespondensi.

E-mail: azka.ramadhona@gmail.com
} 


\section{Teknik, 38 (1), 2017, 41}

Perang Padri. Sejarah Perang Padri dibahas dalam kurikulum Sekolah Dasar (SD) kelas 5. Siswa kelas 5 SD ini diharapkan dapat mengetahui sejarah penjajahan bangsa Eropa di Indonesia dan mengetahui alasan rakyat Indonesia melakukan perlawanan. Sementara itu pelajaran sejarah di sekolah kerap terkendala oleh stigma sebagai pelajaran yang membosankan. Hal ini anggapan bahwa sejarah adalah pelajaran yang "kering", tidak menarik, baik dari segi materi maupun metode belajar, dan tidak penting di tengah berbagai perkembangan keilmuan teknologi dan tuntutan kepraktisan hidup saat ini (Astuti, 2010).

Ini merupakan ironi, di tengah banyaknya pilihan media pembelajaran yang ada sekarang ini. Media pembelajaran yang sudah jamak ditemui sekarang ini adalah Visual Media, Audial Media, Projected still Media, dan Projected Motion Media. Dengan pemilihan media pembelajaran yang tepat diharapkan mampu mempermudah proses belajar-mengajar, meningkatkan efisiensi belajar-mengajar, menjaga relevansi dengan tujuan belajar, membantu konsentrasi, serta merangsang siswa untuk belajar (Haryanto, 2012)

Dalam pembelajaran sejarah, dibutuhkan media pembelajaran yang menarik sehingga materi sejarah mengenai Perang Padri dapat mudah dipelajari serta dapat membantu konsentrasi murid-murid. Salah satu media pembelajaran yang dapat diterapkan adalah melalui video animasi 3D. Video adalah salah satu dari media pembelajaran kategori Projected Motion Media.

Penelitian tentang penggunaan aplikasi 3D pernah dilakukan oleh Suryajaya (2015). Aplikasi ini menggunakan 3DS Max yang ditujukan untuk menghibur pengguna.

Penelitian yang dilakukan kali ini bertujuan untuk meningkatkan minat siswa sekolah dasar dalam mempelajari sejarah. Penelitian ini menghasilkan sebuah aplikasi pembelajaran sejarah "Perang Padri" berbasis video 3 dimensi yang interaktif. Aplikasi ini menggunakan Xbox Kinect dan sensor yang memfungsikan gerakan tangan sebagai kontrol gerakan.

\section{Bahan dan Metode}

Aplikasi pembelajaran interkatif sejarah "Perang Padri" dibuat dengan menggunakan perangkat lunak "Blender". Blender merupakan software pengolah 3 dimensi (3D) yang bisa dijalankan di windows, Macintosh dan Linux. Blender memiliki kelebihan, diantaranya adalah dapat digunakan untuk membuat game dan tidak memerlukan bantuan dari software creator game, karena mempunyai engine sendiri. (Blain, 2011).

Lebih lanjut, aplikasi "Perang Padri" ini dikembangkan dengan bantuan software Kinect for Xbox 360 atau biasanya lebih dikenal sebagai Kinect. Kinect, yang dulu juga disebut sebagai Project Natal, merupakan perangkat yang dibuat oleh Microsoft untuk platform video game Xbox 360. Kinect dapat membantu mengubah cara orang berinteraksi dengan komputer dengan menjadi alat yang dapat menciptakan solusi inovatif yang memungkinkan pengguna untuk berkomunikasi secara alami dengan komputer hanya dengan isyarat atau berbicara. Kinect merupakan perangkat yang dapat menjadikan tubuh jadi sebuah kontrol game, menerima perintah suara dengan mudah (Wiranda, 2012).

\subsection{Gambaran Umum Sistem}

Gambaran umum sistem pembelajaran interaktif sejarag "Perang padre" yang dikembangkan dapat dilihat pada Gambar 1.

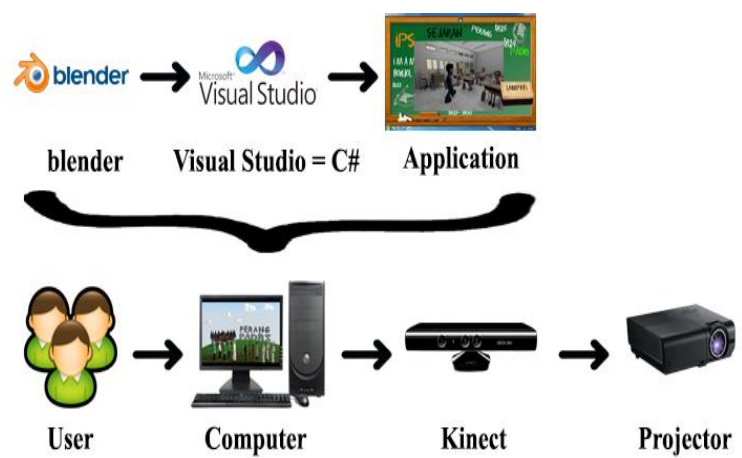

Gambar 1. Gambaran umum sistem

Ilustrasi di atas memberikan gambaran siapa dan apa saja yang berperan dalam penggunaan aplikasi ini, yakni:

1. User (Pengguna) yang berperan sebagai seseorang yang menjalankan aplikasi pembelajaran perang padri ini, yang akan melakukan inputan berupa gerakan tubuh.

2. Computer yang berperan sebagai media untuk merancang video 3D, merancang aplikasi, dan menjalankan aplikasi.

3. Kinect yang berperan sebagai penerima inputan gerakan tangan user, yang akan dikirim dan diproses di dalam komputer.

4. Projector yang berfungsi sebagai output dari aplikasi agar lebih mudah dalam proses pembelajaran di kelas.

\subsection{Use Case Diagram}

Gambaran sistem dari sudut pandang pengguna (user) (Bittner dan Spence, 2003) dapat dilihat dari skenario perancangan use case diagram yang diilustrasikan di Gambar 2. 
Teknik, 37 (2), 2016, 42

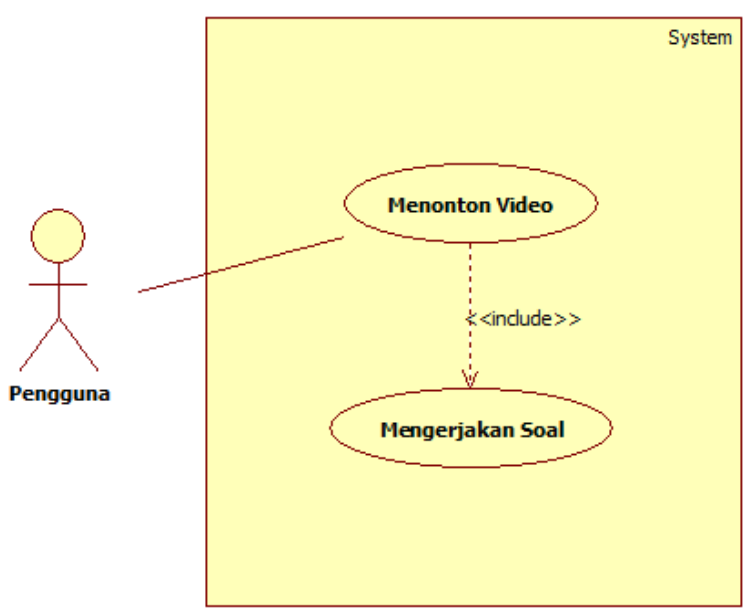

Gambar 2. Use case diagram

Gambar 2 memberikan gambaran tahapan dalam penggunaan sistem, yakni menonton video dan mengerjakan soal. Masing-masing tahap dijelaskan melalui Tabel 1 dan Tabel 2.

Tabel 1. Skenario menonton video

\begin{tabular}{cl}
\hline \multicolumn{1}{c}{ Aktor } & \multicolumn{1}{c}{ Pengguna } \\
\hline Pre kondisi & $\begin{array}{l}\text { Pengguna berada pada halaman } \\
\text { video pembuka. Kemudian } \\
\text { pengguna akan menonton video }\end{array}$ \\
& $\begin{array}{l}\text { Perang Padri. } \\
\text { Pongt kondisi } \\
\text { Penguna selesai menonton } \\
\text { video. }\end{array}$ \\
Deskripsi & $\begin{array}{l}\text { Pengguna menjalankan aplikasi } \\
\text { untuk dapat menonton video }\end{array}$ \\
& Perang Padri. \\
\hline
\end{tabular}

Tabel 2. Skenario mengerjakan soal

\begin{tabular}{cl}
\hline \multicolumn{1}{c}{ Aktor } & \multicolumn{1}{c}{ Pengguna } \\
\hline Pre kondisi & $\begin{array}{l}\text { Pengguna berada pada halaman } \\
\text { soal. }\end{array}$ \\
Post kondisi & $\begin{array}{l}\text { Pengguna selesai mengerjakan } \\
\text { soal. }\end{array}$ \\
Deskripsi & $\begin{array}{l}\text { Pengguna akan diarahkan ke } \\
\text { halaman soal setelah menonton } \\
\text { video. }\end{array}$ \\
\hline
\end{tabular}

\subsection{Flowchart Perancangan Aplikasi}

Diagram alir perancangan aplikasi dapat dilihat pada Gambar 3.

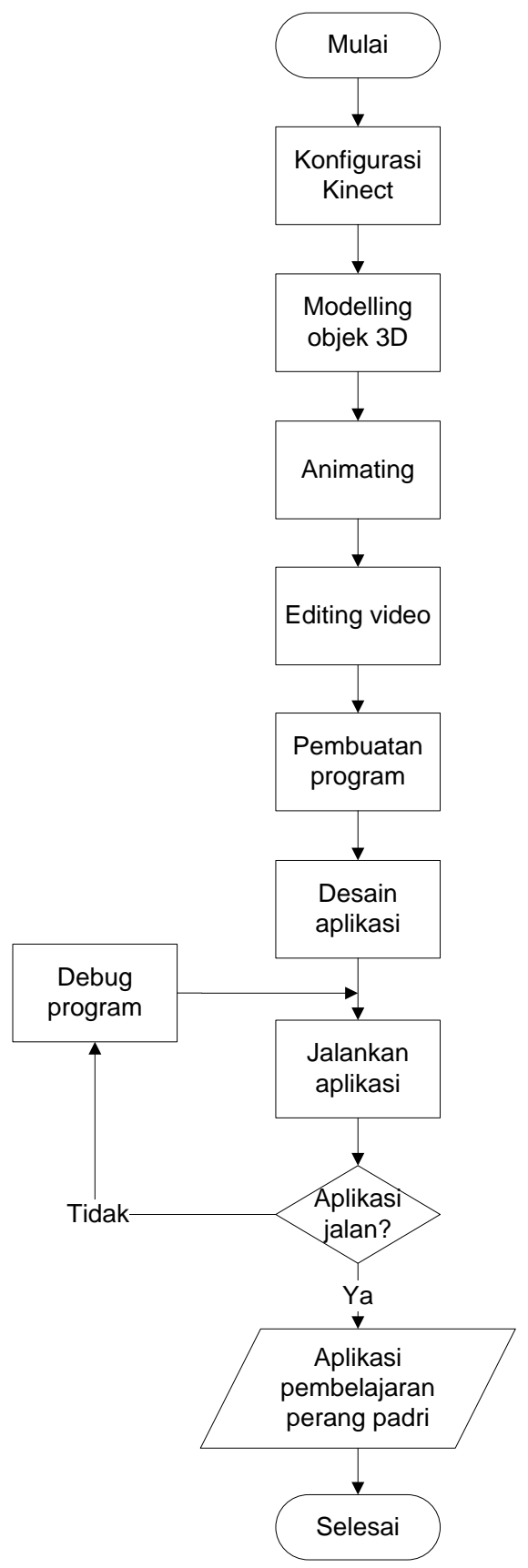

Gambar 3. Flowchart perancangan aplikasi

Aplikasi dibuat dengan memanfaatkan aplikasi Blender untuk pembuatan objek 3D dan animasi. Sedangkan aplikasi desktop yang dirancang menggunakan aplikasi Visual Studio 2010 (Mayo, 2010) dengan menggunakan bahasa C\# (Liberty, 2002).

\subsection{Flowchart Penggunaan Aplikasi}

Diagram alir cara penggunaan aplikasi ditampilkan pada Gambar 4. 
Teknik, 37 (2), 2016, 43

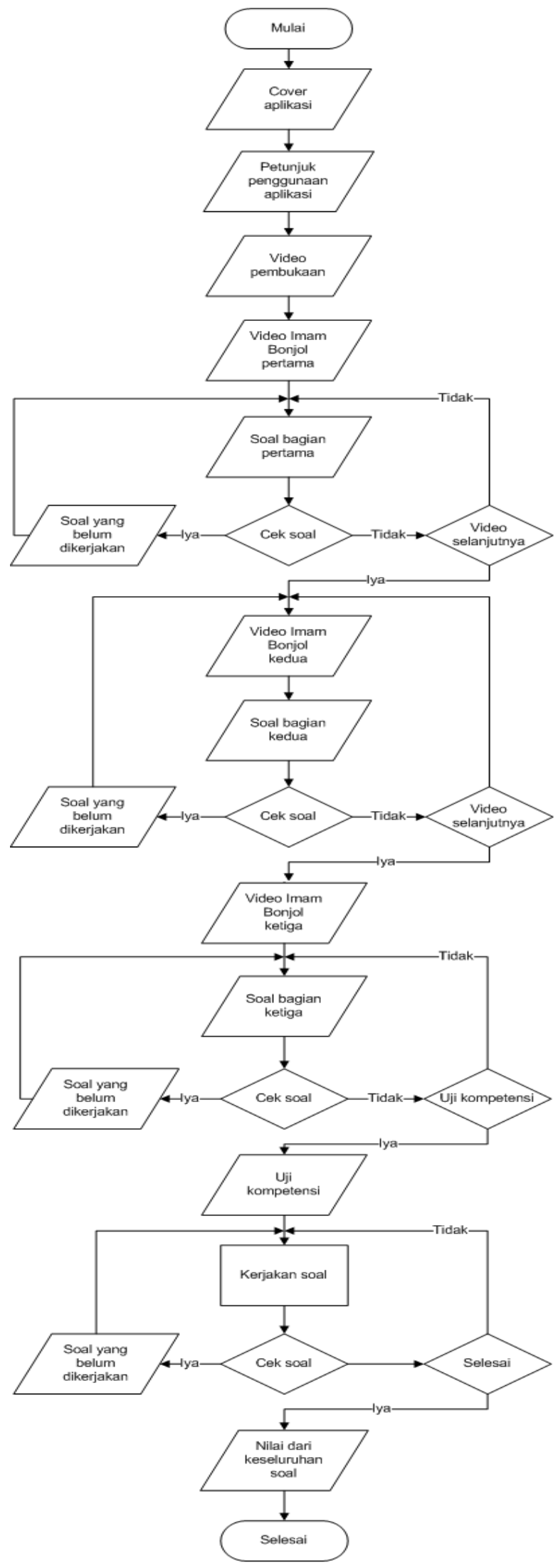

Pada Gambar 4 dapat dilihat alur penggunaan aplikasi. User hanya perlu mendorong (on-click) tombol yang ada.

\section{Hasil dan Pembahasan}

Aplikasi pembelajaran interaktif sejarah "Perang Padri" dibangun sesuai dengan rancangan yang telah dibuat. Gambaran aplikasi dan juga hasil pengujian penggunaan aplikasi ini dapat diuraikan sebagai berikut:

\subsection{Hasil Perancangan Aplikasi}

Gambaran hasil pembangunan aplikasi "Perang Padri" dapat dilihat dari contoh tampilan dan menu aplikasi. Berikut ini adalah contoh tampilan yang ada pada aplikasi "Perang Padri".

1. Halaman depan (cover)

Halaman depan aplikasi yang menampikan judul aplikasi dan ilustrasi ditunjukkan pada Gambar 5 .

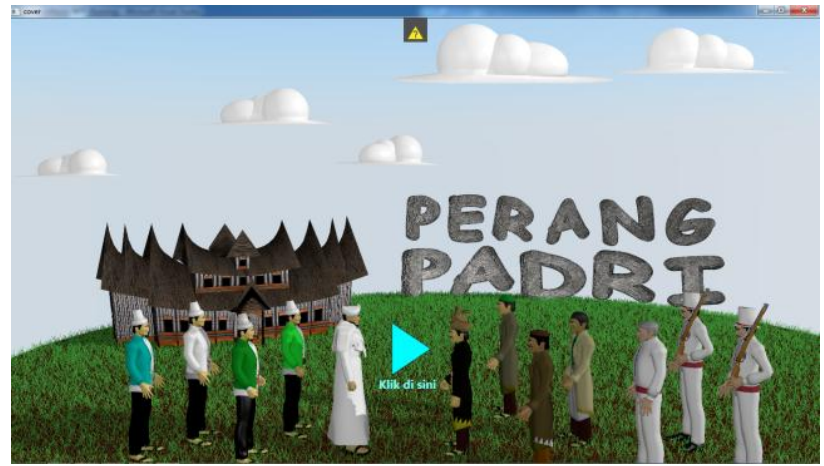

Gambar 5. Cover aplikasi perang padri

\section{Petunjuk}

Aplikasi ini juga meneyediakan petunjuk yang jelas tentang langkah-langkah penggunaannya. Halaman Petunjuk Penggunaan Aplikasi ini dapat dilihat pada Gambar 6.

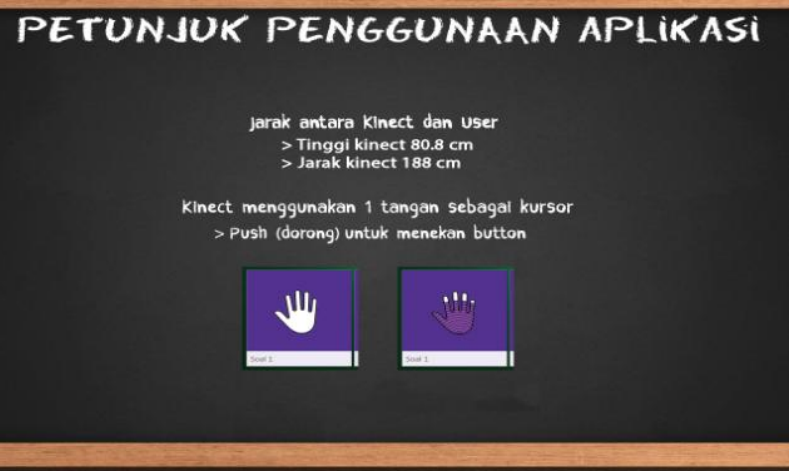

Gambar 6. Halaman petunjuk pengunaan aplikasi

3. Video pembuka

Ilustrasi potongan video pembuka dapat dilihat pada Gambar 7.

Gambar 4. Flowchart penggunaan aplikasi 
Teknik, 37 (2), 2016, 44

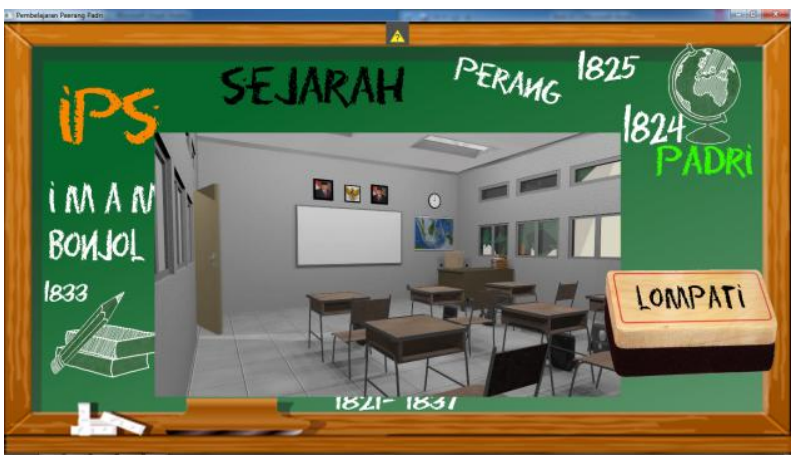

Gambar 7. Halaman video pembuka

\section{Video Sejarah Perang Padri}

Video animasi 3 dimensi Perang Padri yang ditampilkan sesuai dengan kurikulum yang berlaku untuk kelas V Sekolah Dasar. Gambar 8 menunjukkan cuplikan video sejarah Perang Padri.

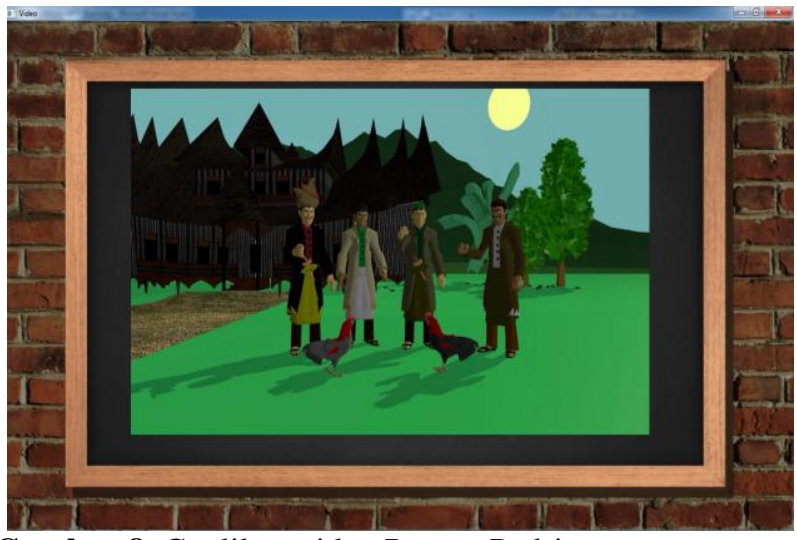

Gambar 8. Cuplikan video Perang Padri

\section{Soal}

Aplikasi ini disertai dengan soal yang diberikan setelah 1 scene selesai. Soal ini menggunakan button yang dapat dipilih dengan cara didorong (on-click). Setelah didorong soal akan muncul. Siswa dapat mengecek soal nomor berapa yang belum diisi. Soal juga dapat dilewati dan akan menampilkan video selanjutnya. Tampilan seperti pada Gambar 9.

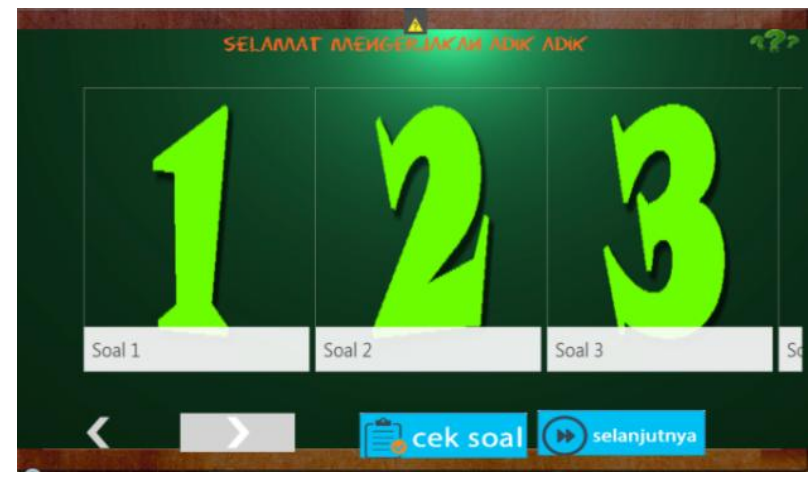

Gambar 9. Halaman soal

\section{Uji Kompetensi}

Selain soal di akhir setiap scene, aplikasi ini juga menyertakan soal di bagian akhir video. Soal di bagian ini dimaksudkan untuk menguji kompetensi siswa dalam memahami materi yang disampaikan melalui video. Tampilan dari halaman uji kompetensi dapat dilihat pada Gambar 10.

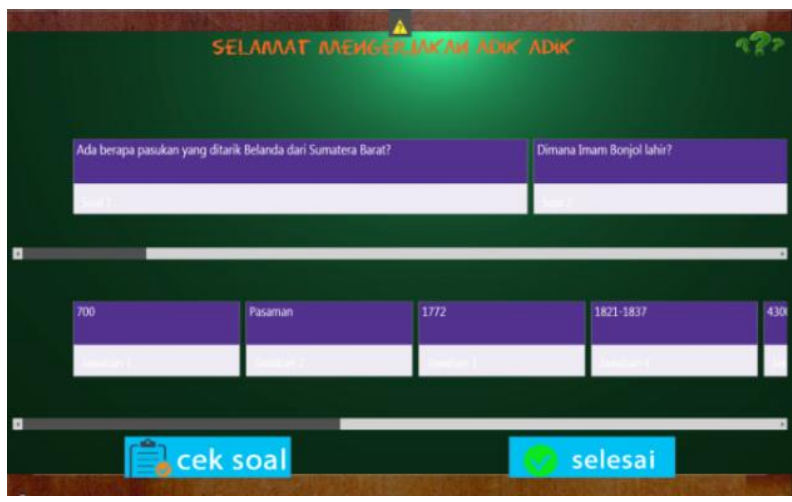

Gambar 10. Halaman uji kompetensi

Dalam uji kompetensi ini siswa mencocokkan soal dengan jawaban. Setelah semuanya telah dicocokkan, siswadapat mendorong button selesai dan kemudian akan muncul nilai pemahaman siswatersebut. Persentase nilai terbagi atas $60 \%$ untuk soal-soal dan $40 \%$ untuk uji kompetensi.

\subsection{Pengujian Aplikasi}

Pengujian aplikasi dilakukan dengan melibatkan pengguna aplikasi. Pengujian dilakukan dengan menggunakan kuesioner berskala Likert, untuk mengumpulkan pendapat pengguna mengenai aplikasi ini. Terdapat dua jenis responden yang akan mengisi kuisioner, yaitu guru dan siswa di SD N 158 Sail Cinta Raja. Jumlah responden guru adalah lima orang dan jumlah responden siswa adalah 40 anak.

\subsubsection{Responden Guru \\ 1. Aspek Materi}

Salah satu hal yang ingin diketahui melalui penyebaran kuesioner adalah pendapat responden guru mengenai kesesuaian dan kelengkapan materi pembelajaran pada aplikasi terhadap kurikulum untuk kelas V SD. Hasil rekapitulasi menunjukkan rata-rata persentase sebesar $90 \%$, seperti yang terlihat pada Tabel 3. 
Teknik, 37 (2), 2016, 45

Tabel 3. Rekapitulasi Hasil Kuesioner Nilai Responden Kategori Aspek Materi

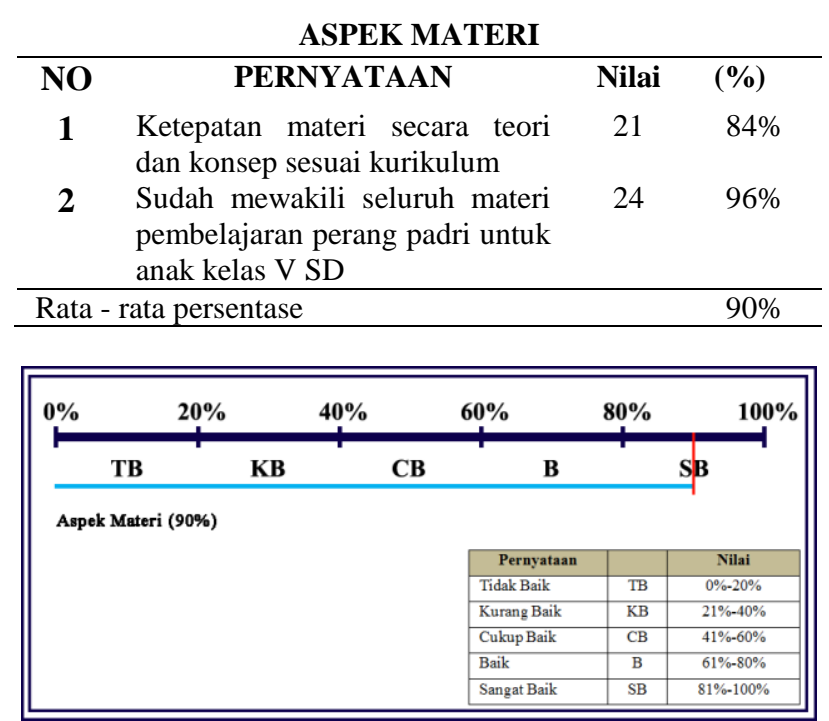

Gambar 11. Skala Likert hasil kuesioner responden guru terhadap Aspek Materi

Gambar 11 menunjukkan bahwa nilai skala Likert untuk aspek materi adalah $90 \%$ sehingga masuk dalam kategori Sangat Baik.

\section{Aspek Umum}

Aspek lain yang ingin diketahui melalui kuesioner adalah pendapat para guru tentang penggunaan aplikasi "Perang Padri" sebagai media pembelajaran alternatif dan apakah aplikasi ini dapat membantu guru dalam melakukan proses pembelajaran. Hasil rekapitulasi menunjukkan rata-rata persentase sebesar $82 \%$, seperti yang terlihat pada Tabel 4.

Tabel 4. Rekapitulasi Hasil Kuesioner Nilai Responden Kategori Aspek Umum

\section{ASPEK UMUM}

\begin{tabular}{clcc}
\hline NO & \multicolumn{1}{c}{ PERNYATAAN } & Nilai & $(\mathbf{\%})$ \\
\hline 1 & $\begin{array}{l}\text { Kandungan materi pembelajaran } \\
\text { perang padri untuk anak kelas V }\end{array}$ & 22 & $88 \%$ \\
& $\begin{array}{l}\text { SD } \\
2\end{array}$ & $\begin{array}{l}\text { Penyampaian informasi } \\
\text { pembelajaran perang padri mudah } \\
\text { dipahami oleh anak kelas V SD }\end{array}$ & \\
3 & $\begin{array}{l}\text { Aplikasi ini membantu guru } \\
\text { dalam melakukan proses } \\
\text { pembelajaran sejarah perang } \\
\text { padri } \\
\text { Aplikasi pembelajaran perang } \\
\text { padri menggunakan deteksi gerak } \\
\text { dapat memudahkan anak kelas V }\end{array}$ & \\
& $\begin{array}{l}\text { SD dan guru dalam memberikan } \\
\text { pembelajaran perang padri yang } \\
\text { edukatif }\end{array}$ & \\
\hline
\end{tabular}

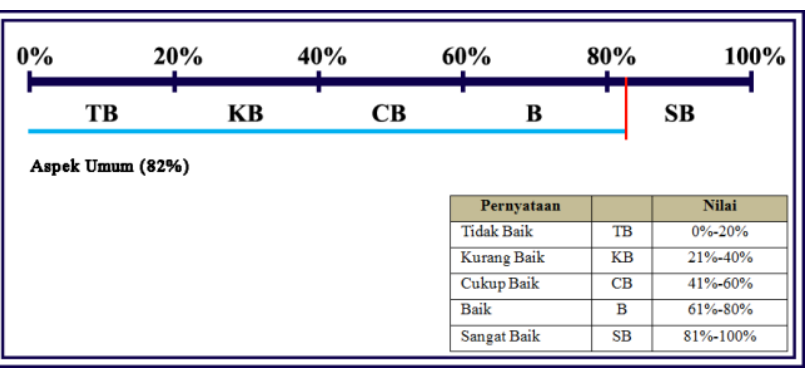

Gambar 12. Skala Likert hasil kuesioner responden guru terhadap Aspek Umum

Berdasarkan Gambar 12 dapat diambil kesimpulan bahwa nilai skala Likert pada responden guru untuk Aspek Umum adalah $82 \%$ sehingga masuk dalam kategori Sangat Baik.

\section{Aspek Tampilan}

Tampilan menjadi aspek lain yang ingin diketahui dari aplikasi "Perang Padri". Responden guru diminta untuk memberikan pendapatnya tentang tampilan, baik berupa kualitas tampilan, penyajian materi, maupun interaksi pengguna.

\subsection{Kualitas Tampilan} Tabel 5.

Hasil rekapitulasi kuesioner tampilan terlihat pada

Tabel 5. Rekapitulasi Hasil Kuesioner Nilai Responden Kategori Aspek Tampilan Pada Kualitas Tampilan

\section{ASPEK TAMPILAN: Kualitas Tampilan}

\begin{tabular}{clcc}
\hline NO & \multicolumn{1}{c}{ PERNYATAAN } & Nilai & $\mathbf{( \% )}$ \\
\hline 1 & Layout aplikasi/penataan konten & 22 & $88 \%$ \\
2 & Petunjuk penggunaan aplikasi & 21 & $84 \%$ \\
3 & Penggunaan bahasa & 18 & $72 \%$ \\
4 & Pemilihan jenis dan ukuran tulisan & 19 & $76 \%$ \\
5 & Pemilihan komposisi warna & 20 & $80 \%$ \\
6 & Kejelasan tulisan & 20 & $80 \%$ \\
7 & Kualitas tampilan gambar & 21 & $84 \%$ \\
8 & Video animasi 3D & 24 & $96 \%$ \\
9 & Musik dan efek suara & 18 & $72 \%$ \\
\hline Rata - rata nilai persentase & & $81,3 \%$ \\
\hline
\end{tabular}


Teknik, 37 (2), 2016, 46

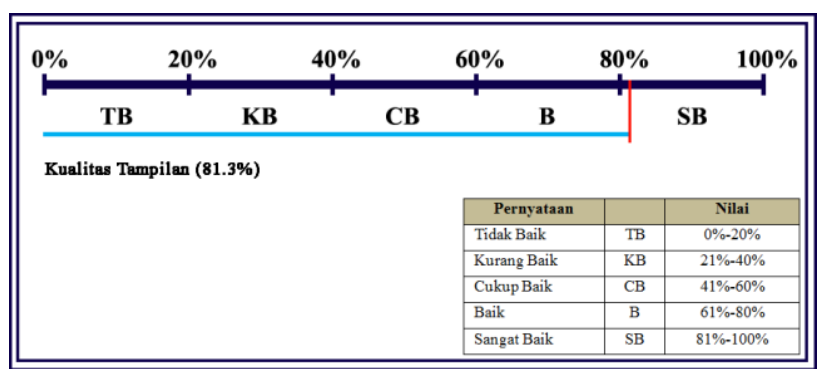

Gambar 13. Skala Likert hasil kuesioner responden guru terhadap Aspek Tampilan-Kualitas Tampilan

Gambar 13 menunjukkan bahwa nilai skala Likert pada responden guru untuk Aspek Tampilan pada Kualitas Tampilan adalah $81,3 \%$ sehingga masuk dalam kategori Sangat Baik.

\subsection{Penyajian Materi}

Rekapitulasi kuisioner terkait penyajian materi adalah dapat dilihat di Tabel 6 dan Gambar 14.

Tabel 6. Rekapitulasi Hasil Kuesioner Nilai Responden Kategori Aspek Tampilan Pada Penyajian Materi

\begin{tabular}{|c|c|c|c|}
\hline \multicolumn{4}{|c|}{ ASPEK TAMPILAN : Penyajian Materi } \\
\hline NO & PERNYATAAN & Nilai & $(\%)$ \\
\hline 1 & Kejelasan tujuan pelajaran & 19 & $76 \%$ \\
\hline 2 & $\begin{array}{l}\text { Kejelasan petunjuk } \\
\text { penggunaan aplikasi }\end{array}$ & 18 & $72 \%$ \\
\hline 3 & $\begin{array}{l}\text { Kemudahan memahami } \\
\text { kalimat pada tulisan }\end{array}$ & 22 & $88 \%$ \\
\hline 4 & Pemahaman materi pelajaran & 20 & $80 \%$ \\
\hline Rata & a nilai persentase & & $79 \%$ \\
\hline
\end{tabular}

\begin{tabular}{|c|c|c|c|c|c|}
\hline $0 \%$ & $20 \%$ & $40 \%$ & $60 \%$ & $80 \%$ & $100 \%$ \\
\hline TB & KB & CB & B & & SB \\
\hline \multicolumn{6}{|c|}{ Penyajian Materi (79\%) } \\
\hline & & & \begin{tabular}{|l} 
Pernyataan \\
\end{tabular} & & Nilai \\
\hline & & & \begin{tabular}{|l|} 
Tidak Baik \\
\end{tabular} & $\mathrm{TB}$ & $0 \%-20 \%$ \\
\hline & & & \begin{tabular}{|l|} 
Kurang Baik \\
\end{tabular} & KB & $21 \%-40 \%$ \\
\hline & & & \begin{tabular}{|l|l} 
Cukup Baik \\
\end{tabular} & $\mathrm{CB}$ & $41 \%-60 \%$ \\
\hline & & & Baik & B & $61 \%-80 \%$ \\
\hline & & & Sangat Baik & SB & $81 \%-100 \%$ \\
\hline
\end{tabular}

Gambar 14. Skala Likert hasil kuesioner responden guru terhadap Aspek Tampilan-Penyajian Materi

Gambar 14 menunjukkan bahwa nilai skala Likert pada responden guru untuk Aspek Tampilan pada Penyajian Materi adalah 79\% sehingga masuk dalam kategori Baik.

\subsection{Interaksi Pengguna}

Rekapitulasi kuisioner terkait aspek interaksi pengguna dapat dilihat di Tabel 7 dan Gambar 15.
Tabel 7. Rekapitulasi Hasil Kuesioner Nilai Responden Kategori Aspek Tampilan Pada Interaksi Pengguna

\begin{tabular}{clcc}
\multicolumn{5}{c}{ ASPEK TAMPILAN: Interaksi Pengguna } \\
\hline NO & \multicolumn{1}{c}{ PERNYATAAN } & Nilai & $(\mathbf{\%})$ \\
\hline $\mathbf{1}$ & $\begin{array}{l}\text { Keaktifan anak didik dalam proses } \\
\text { belajar menggunakan aplikasi ini } \\
\text { Terdapat soal sehingga dapat } \\
\text { menguji kemampuan anak didik } \\
\text { setelah menonton video perang } \\
\text { padri }\end{array}$ & 18 & $72 \%$ \\
$\mathbf{3}$ & $\begin{array}{l}\text { Dapat keluar atau masuk aplikasi } \\
\text { setiap saat }\end{array}$ & 21 & $84 \%$ \\
$\mathbf{4}$ & $\begin{array}{l}\text { Materi atau video perang padri } \\
\text { dapat diulang setiap saat sehingga } \\
\text { meningkatkan daya ingat }\end{array}$ & 22 & $88 \%$ \\
$\mathbf{5}$ & $\begin{array}{l}\text { Respon/umpan } \\
\text { diberikan aplikasi ketika proses } \\
\text { pembelajaran }\end{array}$ & 23 & $92 \%$ \\
\hline Rata - rata nilai persentase & & \\
\hline
\end{tabular}

\begin{tabular}{|c|c|c|c|c|c|}
\hline $0 \%$ & $20 \%$ & $40 \%$ & $60 \%$ & $80 \%$ & $100 \%$ \\
\hline TB & KB & CB & B & & SB \\
\hline \multicolumn{6}{|c|}{ Interaksi Pengguna (84\%) } \\
\hline & & & \begin{tabular}{|l} 
Pernyataan \\
\end{tabular} & & Nilai \\
\hline & & & \begin{tabular}{|l|} 
Tidak Baik \\
\end{tabular} & TB & $0 \%-20 \%$ \\
\hline & & & Kurang Baik & $\mathrm{KB}$ & $21 \%-40 \%$ \\
\hline & & & Cukup Baik & $\mathrm{CB}$ & $41 \%-60 \%$ \\
\hline & & & Baik & B & $61 \%-80 \%$ \\
\hline & & & Sangat Baik & SB & $81 \%-100 \%$ \\
\hline
\end{tabular}

Gambar 15. Skala Likert hasil kuesioner responden guru terhadap Aspek Tampilan-Interaksi Pengguna

Dari Gambar 15 tampak bahwa nilai skala Likert pada responden guru untuk Aspek Tampilan pada Interaksi Pengguna adalah $84 \%$ sehingga masuk dalam kategori Sangat Baik.

\subsubsection{Responden Murid}

Pendapat siswa menjadi bagian penting untuk menilai aplikasi ini. Melalui kuesioner yang diberikan, siswa diminta untuk memberikan pendapatnya terkait dengan Aspek Pembelaran dan Aspek Desain Visual Pembelajaran "Perang Padri".

\section{Aspek Pembelajaran Perang Padri}

Siswa diminta untuk memberikan pendapatnya untuk mengetahui apakah aplikasi ini dapat dikatakan sebagai aplikasi yang interaktif dan dapat dijadikan media pembelajaran alternatif. Hasil rekapitulasi akan pertanyaan-pertanyaan ini dapat dilihat pada Tabel 8 dan Gambar 16. 
Teknik, 37 (2), 2016, 47

Tabel 8. Rekapitulasi Hasil Kuesioner Nilai Responden Kategori Aspek Pembelajaran Perang Padri

\begin{tabular}{|c|c|c|c|}
\hline \multicolumn{4}{|c|}{ ASPEK PEMBELAJARAN PERANG PADRI } \\
\hline NO & PERNYATAAN & Nilai & $(\%)$ \\
\hline 1 & $\begin{array}{l}\text { Aplikasi pembelajaran ini mudah } \\
\text { digunakan }\end{array}$ & 160 & $80 \%$ \\
\hline 2 & $\begin{array}{l}\text { Materi pembelajaran yang } \\
\text { ditampilkan mudah dipahami }\end{array}$ & 166 & $83 \%$ \\
\hline 3 & $\begin{array}{l}\text { Soal-soal yang ditampilkan } \\
\text { mudah untuk dipahami }\end{array}$ & 163 & $\begin{array}{c}81,5 \\
\%\end{array}$ \\
\hline 4 & $\begin{array}{l}\text { Belajar dengan menggunakan } \\
\text { aplikasi ini memberikan } \\
\text { pengalaman belajar yang baru }\end{array}$ & 180 & $90 \%$ \\
\hline 5 & $\begin{array}{l}\text { Aplikasi ini dapat digunakan } \\
\text { kapanpun }\end{array}$ & 146 & $73 \%$ \\
\hline 6 & $\begin{array}{l}\text { Cerita sejarah perang padri yang } \\
\text { ditonton dapat ditangkap } \\
\text { maksudnya }\end{array}$ & 169 & $\begin{array}{c}84,5 \\
\%\end{array}$ \\
\hline Rata & rata nilai persentase & & $82 \%$ \\
\hline
\end{tabular}

\begin{tabular}{|c|c|c|c|c|c|}
\hline \multirow[t]{2}{*}{$0 \%$} & $20 \%$ & $40 \%$ & $60 \%$ & $80 \%$ & $100 \%$ \\
\hline & KB & CB & B & & SB \\
\hline \multicolumn{6}{|c|}{$\begin{array}{l}\text { Aspek Pembelajaran } \\
\text { Peria }\end{array}$} \\
\hline \multirow{6}{*}{\multicolumn{2}{|c|}{ Perang Padri (82\%) }} & & \begin{tabular}{|l|l|} 
Pernyataan \\
\end{tabular} & & Nilai \\
\hline & & & Tidak Baik & $\mathrm{TB}$ & $0 \%-20 \%$ \\
\hline & & & Kurang Baik & $\mathrm{KB}$ & $21 \%-40 \%$ \\
\hline & & & Cukup Baik & CB & $41 \%-60 \%$ \\
\hline & & & \begin{tabular}{|l|} 
Baik \\
\end{tabular} & B & $61 \%-80 \%$ \\
\hline & & & \begin{tabular}{|l|} 
Sangat Baik \\
\end{tabular} & SB & $81 \%-100 \%$ \\
\hline
\end{tabular}

Gambar 16. Skala Likert hasil kuesioner responden siswa terhadap Aspek Pembelajaran

Gambar 16 menunjukkan bahwa nilai skala Likert siswa terhadap Aspek Pembelajaran Perang Padri adalah $82 \%$ sehingga masuk kategori Sangat Baik.

\section{Aspek Desain Visual Pembelajaran Perang Padri}

Penilaian Aspek Desain Visual Pembelajaran dari aplikasi dapat dilihat pada Tabel 9 dan Gambar 17.

Tabel 9. Rekapitulasi Hasil Kuesioner Nilai Responden Kategori Aspek Pembelajaran Perang Padri

\begin{tabular}{|c|c|c|c|}
\hline \multicolumn{4}{|c|}{$\begin{array}{l}\text { ASPEK DESAIN VISUAL PEMBELAJARAN } \\
\text { PERANG PADRI }\end{array}$} \\
\hline NO & PERNYATAAN & Nilai & $(\%)$ \\
\hline 1 & $\begin{array}{l}\text { Penggunaan jenis huruf dan } \\
\text { ukuran huruf }\end{array}$ & 150 & $75 \%$ \\
\hline 2 & Desain tampilan & 172 & $86 \%$ \\
\hline 3 & Penggunaan warna dan gambar & 163 & $81.5 \%$ \\
\hline 4 & $\begin{array}{l}\text { Keterangan teks pada objek } \\
\text { pembelajaran dapat membantu } \\
\text { penjelasan materi }\end{array}$ & 161 & $80,5 \%$ \\
\hline 5 & $\begin{array}{l}\text { Kesesuaian inputan gerakan } \\
\text { tangan dengan respon dari } \\
\text { aplikasi }\end{array}$ & 147 & $73,5 \%$ \\
\hline Rat & rata nilai persentase & & $79,3 \%$ \\
\hline
\end{tabular}

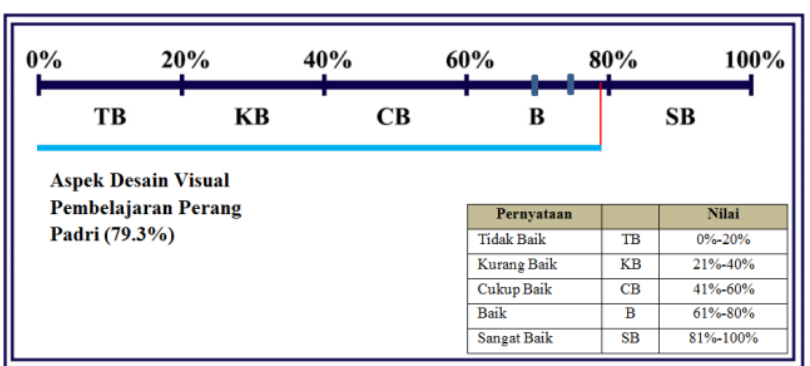

Gambar 17. Skala Likert hasil kuesioner responden siswa terhadap Aspek Desain Visual Pembelajaran Perang Padri

Gambar 17 menunjukkan bahwa nilai skala Likert siswa terhadap Aspek Desain Visual Pembelajaran Perang Padri adalah 79,3\% sehingga masuk dalam kategori Baik.

\section{Kesimpulan}

Penelitian ini berhasil mengembangkan sebuah aplikasi pembelajaran interaktif sejarah "Perang Padri" berbasis video 3 dimensi menggunakan Xbox Kinect dan gerakan tangan sebagai kontrol gerakan. Kuisioner dari responden lima guru dan 40 siswa yang menggunakan aplikasi ini memberikan penilaian Baik dan Sangat Baik untuk Aspek Kualitas Tampilan, Penyajian Materi, Desain Visual, dan Interaksi Pengguna.

Hasil evaluasi menunjukkan bahwa penyajian materi pelajaran sejarah melalui aplikasi yang dikembangkan mampu meningkatkan secara signifikan minat siswa Sekolah Dasar dalam mempelajari sejarah bangsa Indonesia.

Untuk pengembangan selanjutnya, materi yang disampaikan dalam aplikasi ini dapat diperluas dengan materi lain dari pelajaran sejarah bangsa Indonesia. Pengembangan aspek teknis bisa dilakukan dengan menggunakan compressor video yang tidak merusak kualitas video. Selain kedua hal tersebut, bisa dilakukan penambahan jenis game pada aplikasi ini untuk dapat meningkatkan minat belajar siswa terhadap pelajaran sejarah

\section{Daftar Pustaka}

Astuti, Palupi Panca. (2010). Jejak Sejarah Masih Terbelenggu. Diakses dari http://edukasi.kompas.com/read/2010/07/09/05473 188/Jejak.Sejarah.Masih. tanggal 6 Januari 2014.

Bittner, Kurt \& Spence, Ian. (2003). Use Case Modelling. Boston: Addison Wesley.

Blain, J.M. (2011). An introduction to BLENDER $3 D$ a book for beginners. Europe : Blender Foundation.

Haryanto. (2012). Pengertian Media Pembelajaran. Diakses dari dari http://belajarpsikologi.com/pengertian-mediapembelajaran/. tanggal 3 Januari 2014.

Liberty, Jesse. (2002). Learning C\#. California:O'Reilly. 
Teknik, 37 (2), 2016, 48

Mayo, Joe. Microsoft Visual Studio 2010: a beginners' guide. (2010) New York: McGraw-Hill.

Suryajaya, I Dewa Bagas. (2015). Teknik motion capture dalam proses pembuatan animasi $3 D$ mengunakan microsoft kinect. Diakses dari http://ojs.amikom.ac.id/index.php/semnasteknomed ia/article/view/835/799.
Wiranda, Nuruddin. (2012). Implementasi Kinect pada Penerjemah Bahasa Isyarat. Sekolah Tinggi Managemen Informatika dan Komputer Amikom Yogyakarta. Tidak dipublikasikan. 